Rev. Jarostaw Wojtkun

Katolicki Uniwersytet Lubelski Jana Pawła II

\title{
Archbishop Zygmunt Zimowski's Contribution to Shaping Health Care as a Guardian and Servant of Life
}

The recently deceased Archbishop Zygmunt Zimowski, former President of the Pontifical Council for Health Care Workers, which was incorporated into the Dicastery for Promoting Integral Human Development, worked tirelessly to guide and support the sick and suffering who have a right to medical care as well as health care workers in an increasingly complex world. This article presents the mission of health care professionals as a service of the various dimensions of life. This form of service strives to restore harmony to life and integrate not only the body's vital functions but also the physical, spiritual, psychological, and religious spheres of human life. The action of God, who often assumes the role of a physician in the Bible, is the model of such service. Healthcare serves to restore life to its full dynamism and individuals to the ability to live life to its full potential. It is also a service of the sanctity and Gospel of life, which guides healthcare professionals'special relationship with the sick and the reality of suffering.

Key words: the disease, illness, service, life.

\section{Introduction}

In December 2016, the President of what was the Pontifical Council for Health Care Workers, the late Archbishop Zygmunt Zimowski signed and published the dicastery's final official document entitled "A New Card for Health Care Workers." This document's introduction 


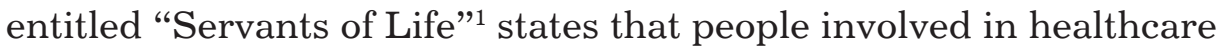
are the "guardians and servants of life" not only in terms of physical life, but also in terms of psychological, religious, and spiritual life. When introducing the New Card, Archbishop Zimowski emphasized that, while healthcare institutions and their administrative systems are important, neither can replace the human heart or fulfill their functions without having compassion in the face of the reality of human suffering. ${ }^{3}$

Due to the multitude of healthcare specializations, medical treatment today is entrusted to healthcare specialists. However, every medical specialist serves to some degree as a general practitioner whose must "embrace first of all the totality of bodily organs and functions [and] be acquainted with the patient's family, his milieu, his whole medical history. [... Physicians] should unceasingly make the effort to keep in mind the profound unity of the human being, in the evident interaction of all his bodily functions, but also in the unity of his bodily, affective, intellectual and spiritual dimensions." ${ }^{4}$ This task specifies the particular dignity of the mission of healthcare professionals; for, a doctor's work can be compared to the working of God himself. God behaves toward man like a doctor toward a patient.

\section{The Divine Model of Care for Life}

God gives man health of body in the context of temporality and health of soul in the context of eternity. Thanks to this, the work of health care professionals has particular religious value. For, we can say that doctors not only carry out their professional roles, they also serve as ministers of life in the field of health care. ${ }^{5}$

1 The Italian text use the phrase "ministri della vita," which literally means "ministry of life."

2 Pontifical Council for Healthcare Workers, Nuova Carta degli Operatori Sanitari (Vatican City, Italy: Libreria Editrice Vaticana, 2016), 9. When this article was submitted for publication, the English translation of this text did (and does not) yet exist. Hereafter this document will be referred to as PCHCW, Nuova Carta. PCHCW, Nuova Carta, 3.

4 John Paul II, "Address at the Conclusion of the $35^{\text {th }}$ General Assembly of the World Medical Association," October 29, 1983 (Vatican City, Italy: Libreria Editrice Vaticana, 1983), https://w2.vatican.va/content/john-paul-ii/en/speeches/1983/october/documents/hf_jp-ii_spe_19831029_ass-medica-mondiale.html, (Accessed 10.17.2017).

According to Professor Jacek Imiela, who is a national consultant in internal medicine, this definition is not the most appropriate. In other countries, other 
A doctor who cares for the ill and suffering imitates God himself. The Book of Tobit reveals that the name of the Archangel Raphael means "God heals" and "God cures," which exemplifies God's mode of action, which encompasses caring for the sick.

Often in the books of the Old Testament we encounter a God who has "torn, but will [...] heal" and has "struck down, but [...] will bind up" (Hosea 6:1). In this way, a person can imitate God even in a mundane activity like sterilizing and dressing a wound. We also find this image in Psalm 147:3, which is a hymn of gratitude to God who "heal[s] the brokenhearted, and bind[s] up their wounds."

Can the nurses who prepare beds for the sick find something pertinent in this biblical message? Of course! In Psalm 41:4, the person praying expresses sadness because of his illness-related ailments, and God, who "sustains him on his sickbed" and "turn[s] down his bedding whenever he is ill," comes to his aid. Here God is depicted as a nurse dressed in a white uniform performing daily duties in a hospital room. Commenting on Psalm 41, St. John Paul II recognizes that "the voice of the person praying Psalm [41] speaks to the multitude of people who are forgotten and humiliated in their illness and weakness, even by those who should support them." 6

Reverend Professor Waldemar Chrostowski presents a very interesting and even humorous interpretation of God's action as a physician. He reveals that the act of creation in the Book of Genesis is carried out in a manner typical not only of a doctor, but a specialist in four fields of medicine. ${ }^{7}$ God created man, placed him in the Garden of Eden, stated that "It is not good for the man to be alone" (Genesis 2:18), and then began to act. He creates Eve in a manner that one would see in a hospital: "So the LORD God cast a deep sleep on the man;" here God is presented as an anesthesiologist. Genesis continues: "While he was asleep, he took out one of [Adam's] ribs;" here God behaves like an orthopedic doctor. Then God " closed up its place with flesh;" here he acts as a surgeon. Genesis goes on, "The LORD God then built the

terms are used such as: "Service of Suffering," and "Service of Death," which, according to Professor Imiela, expresses more accurately what the medical community really does . See J. Imiela, "Cierpienie - spojrzenie lekarza," Ból i cierpienie - ognisko światta i ciemności. Medycyna - Teologia-Kultura, Vol. 4, ed. D. Pater (Warsaw: 2016), 11. XVI rozważaja Psalmy, (Izabelin-Warsaw: Rosikon Press, 2006), 99. 
rib that he had taken from the man into a woman" (Gen. 2:21-22); and here God is a plastic surgeon.

Moral theology

\section{Doctors-Serving Others to Bring about Harmony of Life}

God, the Creator of life, shared with man the care of life. In this regard, doctors play a special role. In the creation of the world, God brought harmony out of the primordial chaos. The cosmos originated from what is known in Greek as "order." The task of healing is more or less the same: ${ }^{8}$ to restore harmony to a body disordered by disease. ${ }^{9}$

The similarity between the work of health professionals and the God's work of creation also depends on properties concealed in nature. Ben Sira notes this reality in the Book of Sirach 38:4-11:

God makes the earth yield healing herbs

which the prudent should not neglect;

Was not the water sweetened by a twig,

so that all might learn his power?

He endows people with knowledge,

to glory in his mighty works,

Through which the doctor eases pain, and the druggist prepares his medicines.

Thus God's work continues without cease in its efficacy on the surface of the earth.

My son, when you are ill, do not delay, but pray to God, for it is he who heals.

Flee wickedness and purify your hands;

cleanse your heart of every sin.

Offer your sweet-smelling oblation and memorial,

a generous offering according to your means.

God is the Creator of nature, from which it is possible to obtain the medicine necessary to heal diseases. Serving others by healing and relieving suffering is an extension of the work of creation. The therapeutic use of the elements of nature is also a way to fulfill God's divine command to Adam to subdue the earth (see Gen. 1:28). Being a servant of the harmony of life extends beyond the physical dimension of the body, however; for, the restoration of health brings greater order and harmony to every sphere of human existence and activity.

8

This is "more or less" the result of the alleged inaccuracy of this comparison, which is due to the writer's insufficient competence in the field of medicine. 


\section{Service of Life and its Many Dimensions}

Therapeutic outcomes depend greatly on a patient's cooperation with the physician as well as the treatment. Treatment, however, cannot be reduced only to restoring the body's proper function; instead, it should take into consideration the whole person-spirit, emotions, and psyche. In this regard, a doctor should strive to heal not the disease that affects a person, but rather the person affected by disease. St. John Paul II began this trend by distinguishing between pain and suffering: "Man suffers in different ways, ways not always considered by medicine, not even in its most advanced specializations. Suffering is something which is still wider than sickness, more complex and at the same time still more deeply rooted in humanity itself. A certain idea of this problem comes to us from the distinction between physical suffering and moral suffering. This distinction is based upon the double dimension of the human being and indicates the bodily and spiritual element as the immediate or direct subject of suffering. Insofar as the words 'suffering' and 'pain,' can, up to a certain degree, be used as synonyms, physical suffering is present when 'the body is hurting' in some way, whereas moral suffering is 'pain of the soul.' In fact, it is a question of pain of a spiritual nature, and not only of the 'psychological' dimension of pain which accompanies both moral and physical suffering." 10

The matter of pain and suffering was always dear to Archbishop Zygmunt Zimowski. As the head of the Pontifical Council for Healthcare Workers, he spoke on world days dedicated to specific kinds of disease and illness. From among the many diseases that exist, he chose to mention those that would elicit sympathy. In addition, he wanted to draw particular attention to those suffering from rare and forgotten diseases. As is clear from his messages, he especially cared about the fate of those who suffer from leprosy and demanded that their rights be recognized. He regretted that, "unfortunately, even today those who suffer from this disease, and even after they are cured of it, are disfigured by its effects and often condemned to loneliness. They live in fear and must disappear from public view and opinion. In economically advanced countries, it is as if this disease has been forgotten about, just as those who are afflicted by it have been forgotten."11

10 John Paul II, Apostolic Letter: Salvifici Doloris (Vatican City, Italy: Liberia Editrice Vaticana, 1984), 5.

11 Z.Zimowski, Message of the President of the Pontifical Council for the Sick and Pastoral Care of Healthcare Workers (January 31, 2010), http://archbishopterry. blogspot.com/2010/01/ (Accessed:10.13.2017). 
Moral theology

In his work Treatise on Asthma, which is largely based on the Bible, the medieval philosopher and physician Moses Maimonides, who practiced medicine at the court of Sultan Saladyn and who wrote the treatise for his patient Prince Al-Afdala, sets forth the following principles of the healing process: "There is a general rule, and I have seen great doctors adhere to it: a doctor should not treat the disease but rather the person suffering from it," and "Doctors do not know how to cure many diseases because they do not know the whole person; a part cannot be healthy unless the whole is healthy." 12

A doctor knows that he is a servant-and not the master-of life; for, God is the master and source of life. An authority does not have complete control over that which has been entrusted to him. Therefore, a doctor is a cooperator with God. His medical knowledge and specialization acquired through years of study and practice equip him to be an authority on the life. God, the Author of Life, has entrusted to him this good and vocation. It is for this reason that we say that being a doctor is a vocation.

Part of treatment is entrusted to the doctor, while the other part is reserved for God. In the Book of Sirach, Ben Sira says about the doctor: "He too prays to God / That his diagnosis may be correct / and his treatment bring about a cure" (38:14). Archbishop Zimowski was convinced that the doctor's ability to help those who are suffering from diseases of the body and soul comes not only from his medical knowledge but also from God's grace. When referring to Benedict XVI's message entitled "God and do likewise (Luke 10:37)" that he delivered on the World Day of the Sick 2013, Archbishop Zimowski said: "The ability to bring relief to the sick is not the effect only of our abilities or efforts; rather, it is the result of our union with Christ that has been nourished through a life of faith, prayer, and practice."13

When a doctor restores a patient's health, then the patient's potential to do good, which was limited by his disease, is unblocked. In this way, a doctor restores not only the functions of the body, but also liberates new energies of life.

12 See W. Chrostowski, Lekarz i jego postuga, 65, note 7. Such wise reflections from individuals who lived during the Middle Ages forces one to question whether the so-called Dark Ages were really so "dark" after all.

$13 \quad$ Z.Zimowski, "Conferrenza Stampadipresentazionedella XXIGiornata Mondiale del Malato 11 02.2013 [Press Release on the XXI World Day of the Sick on February 11, 2013]," (Vatican City: January 20, 2013), http://www.vatican.va/roman_curia/ pontifical_councils/hlthwork/documents/rc_pc_hlthwork_doc_20130129_worldday-of-the-sick_it.html, (Accessed: 06.06.2017). 


\section{Servant of the Vigor of Life}

When a person's health is restored, his life is enriched with new spiritual energies that are transformed into the potential to do good to others. Therefore, the restoration of health is the first link in great chain of good. This order of events is clear in Jesus' healings. Jesus healed the lame man at the well of Bethesda not only so that he could walk, but also so that he would "not sin any more, so that nothing worse may happen to [him]" (John 5:14). The man had to go in order to do good and not just avoid evil. ${ }^{14}$ Jesus' words were the first that those who were deaf heard when Jesus healed them. These words were so powerful that they effected in a complete transformation of life and not just the restoration of health in those who were healed. ${ }^{15}$ The blind not only received the ability to see, they also received the light of faith. The man who was blind from birth, whom Jesus told to wash in the Pool of Siloam, wanted to worship the one who healed him. And Jesus, referring to Himself said, "You have seen him and the one speaking with you is he" (John 9:37). ${ }^{16}$

This reality did not escape Archbishop Zygmunt Zimowski's attention when he discussed the healing of the ten lepers. He shared that "The faith of the lone leper who, on seeing that he was healed, full of amazement and joy, and unlike the others, immediately went back to Jesus to express his gratitude, enables us to perceive that reacquired

$14 \quad$ "When meeting with the man he healed in the temple, Jesus makes it clear to the man that the favor he has granted him is supernatural. When referring to the popular belief that illness and disability are the consequence of sin, Jesus calls on the healed young man to respond appropriately to his experience of grace by leading an impeccable spiritual and moral life" in K. Romaniuk, A. Jankowski, and L. Stachowiak, Komentarz praktyczny do Nowego Testamentu, Vol. 1 (Poznan-Cracow: Wydawnictwo WAM, 1999), 451.

How much it means to a deaf man to have his hearing restored to him depends on how much his lack of hearing affected his life. The ability to hear has a significant influence on the quality of a person's life, on his ability to communicate with his surroundings, to work, to rest; basically, it affects everything. Therefore, it is very important for a person to have his hearing restored and, when this happens, it has a significant impact on his life. See H. Skarżyński, "Niedosłuch i głuchota przyczyną izolacji, bólu i cierpienia," Ból i cierpienie ognisko światła i ciemności. Medycyna-Teologia-Kultura, Vol. 3, ed. D. Bard (Warsaw: 2015), 9.

16 "Jesus response is personal and unrepeatable. He points to himself as the subject of the man's experience of sight and as the one who communicates with the young man through words. [...] This sight is contemplation. In order to see the Son of Man, it is not enough to be able to physically see; rather, what is necessary is spiritual sight." S. Mędala, Ewangelia wedtug świętego Jana, rozdziaty 1-12, no.1 (Częstochowa: Edycja Świętego Pawła, 2010), 731. 
Moral theology

health is a sign of something more precious than mere physical healing, it is a sign of the salvation that God gives us through Christ; it finds expression in the words of Jesus: your faith has saved you. $\mathrm{He}$ who in suffering and illness prays to the Lord is certain that God's love will never abandon him, and also that the love of the Church, the extension in time of the Lord's saving work, will never fail.' [Physical healing - the manifestation of deeper healing - simultaneously shows how much the whole person—both body and soul—mean to Christ]."17

Caring for someone who is sick and showing him compassion gives a person the opportunity to heal not only physically, but also spiritually and emotionally. It also gives him an opportunity to see everything in a new way. From this perspective, Pope Francis' slogan for the 2015 World Day of the Sick is significant. The slogan comes from Job: "I was eyes to the blind, and feet to the lame was I" (29:15). Those who need help also need someone who can help them see ("eyes to the blind") and to navigate ("feet to the lame") their experience of sickness and suffering.

A patient's contact with health care professionals gives him the opportunity to see dimensions of his situation that have been hitherto overlooked or unnoticed. Establishing this contact is a movement in a new direction. Someone suffering can help those who care for him perceive things more clearly. When speaking to the sick, John Paul II drew people's attention to this dimension: "[Y]ou in return give much to us. Your ailments make us aware of the frailty of human life, of its dangers and limitations. They also remind us that one cannot do everything one wants to, that not everything one starts can be completed. [...] You know better now what matters in life. By telling us, by showing us what you are experiencing now and by the way in which you tolerate it, you can communicate to us a wisdom of life chastened and matured through your suffering. The Pope thanks you for preaching to us through the patience with which you bear your sufferings. Your example cannot be replaced by any pulpit, school, or lecture. The sickroom teaches a people as much as classrooms and lecture halls." 18

$17 \quad$ Z.Zimowski, "Message of the President of the Pontifical Council for Health Care Workers on the Occasion of the 59 ${ }^{\text {th }}$ World Leprosy Day" (January 29, 2012), http://www.vatican.va/roman_curia/pontifical_councils/hlthwork/documents/ rc_pc_hlthwork_doc_20120127_lebbra_en.html

18 John Paul II, "Address to the Elderly and the Sick, 'Your Suffering is Part of Christ's Cross," World Federation of the Catholic Medical Associations (September 11, 1983), http://www.fiamc.org/texts/your-suffering-is-part-of-christs-cross/ (Accessed 10.17.2017). 
The sick have a certain spiritual treasure that they can share with to those who are healthy. Those who are genetically healthy need the handicapped, such as those with Down's Syndrome, to learn from them how to live joyfully. And those who are alive need the dying to teach them the art of living a beautiful life. In this way, solidarity amongst men is created. In this regard, Archbishop Zimowski said that "sharing in another's situation, whoever he might be, is to share in his suffering. This includes creating and implementing integrative ways to assist and support the suffering. Therefore, the ethics of solidarity cannot be reduced solely to the indispensible work of social institutions, nor is it exclusively entrusted to those who carry out certain professions. The other is someone who is able to see not only a person, but the fact that this person is in need." 19 This does not change the fact that "they are close to the sick in need of constant care and help in washing, dressing and eating. This service, especially when it is protracted, can become tiring and burdensome. It is relatively easy to help someone for a few days but it is difficult to look after a person for months or even years, in some cases when he or she is no longer capable of expressing gratitude." 20

The clerics of the seminary in Radom regularly visit the terminally ill at the Queen of the Apostles Hospice. These men not only have the opportunity to accompany the terminally ill, but they also benefit from the spiritual riches that come from experiencing and witnessing the final stage of life. During their visits to the hospice, the clerics accompany the chaplains and health care workers, participate in the final moments of lives of the terminally ill, and share in the sorrow of the families left behind. The formation that this contact enables is of inestimable value. ${ }^{21}$ No lecture or test taken at school could ever replace the knowledge that these men gain from such an experience.

$19 \quad$ Z.Zimowski, "Messaggio del Presidente del Pontificio Consiglio per gli Oparatori Sanitari in occasione della IX Giornata Mondiale delle Malattie Rare 22 febbraio 2016 [Message of the President of the Pontifical Council for Health Care Workers on the Occasion of the $9^{\text {th }}$ World Day of Rare Diseases]" (February 22, 2016), http://www.vatican.va/roman_curia/pontifical_councils/hlthwork/documents/ rc_pc_hlthwork_doc_20160229_malattie-rare_it.html (Accessed: 11.15.2016).

20 Francis, "Message His Holiness for the $23^{\text {rd }}$ World Day of the Sick 2015," February 2, 2015 (Vatican City, Italy: Libreria Editrice Vaticana, 2015), 2, https:// w2.vatican.va/content/francesco/en/messages/sick/documents/papa-francesco_20141203_giornata-malato.html.

21 To read more on this topic see J. Wojtkun, "Posługa hospicyjna alumnów jako element formacji do kapłaństwa," Musicam Sacram dilexit. Księga pamiatkowa dedykowana Księdzu Henrykowi Ćwiekowi profesorowi wyższych seminariów duchownych w Sandomierzu i Radomiu: Studia i materiaty,” eds. M. Jagodziński, 
Moral theology

A special exchange of spiritual gifts occurs through contact with the dying. On the one hand, those who care for the sick give the sick relief. On the other hand, they experience the mysterious impact of the dignity of the dying and the beauty of their faces.

Those who accompany the dying have an opportunity to experience new dimensions of life that the dying are unable to show contemporary society. For, today's society is immersed in a culture that is afraid to look death in the face. And, if it is not possible for society to get rid of death, then society wants to at least isolate the dying. In doing so, society rids itself of the possibility to take advantage of the wisdom that only the dying can share. The one who accompanies the dying experiences the riches of a lesson that he wants to share with the living. ${ }^{22}$ The personal testimony of one of the clerics who visits the hospice is a perfect illustration of this truth:

We arrive with Dr. Maria, who is a nurse and volunteer. The sick person was in serious condition. Fortunately, his entire family was surrounding and supporting him. The doctor examined the sick man and tried to communicate with him, although it was difficult. While this occurred, the other volunteers and I talked with the family. They told us how much good they received from their sick loved one-how he cared for the entire family, and how he is a good person. At one moment, Dr. Maria and I approached the sick man, and I could see how greatly he was suffering. My attention turned to the patient's eyes-eyes that were filled with joy and the desire to live. When we returned to the hospice on Wiejska Street, I asked Dr. Maria about this man's eyes, and I was shocked by her answer! Dr. Maria said that that is what a person's eyes look like a few hours before death. It was true; the following day the sick man's funeral took place. The thought that I will be in the same situation one day came to mind. A person might have only a few moments of life left on the earth, and yet his eyes can express his longing to live. ${ }^{23}$

Despite the difficulties and inconveniences of caring for the sick, Pope Francis uses the loftiest terms when speaking about the time that one spends at the bedside of the sick: "Time spent with the sick is holy time. [...] Occasionally our world forgets the special value of time spent at the bedside of the sick, since we are in such a rush; caught

S. Kowalik, and A. Wąsik (Radom: Wyższe Seminarium Duchowne; Instytut Technologii Eksploatacji-Państwowy Instytut Badawczy, 2017), 313-322.

See V. Paglia, Sorella morte. La dignità del vivere e del morire (Milan: Pickwick, 2016), 94 .

23 This was published on the website of the Higher Seminary in Radom, September 20, 2014, www.seminarium.radom.pl. 
up as we are in a frenzy of doing, of producing, we forget about giving ourselves freely, taking care of others, being responsible for others."24

\section{Service of the Sanctity of Life}

Contact with the sick is a unique opportunity to enter into a mystical reality. The world of the sick is where one can spiritually experience an encounter with the suffering Christ. Pope Francis' meeting with the sick in Assisi in October 2013 was a moving image of this reality. Putting aside the text that he had previously prepared and setting his gaze on the sick children in wheelchairs, the Holy Father said: "here we contemplate the wounds of Christ. Christ's wounds are here. Looking upon those who are infirm and touching their pain, in its simplicity, in its misery and hurt, we touch the wounds of Christ. Here we are contemplating the wounds of Christ. ${ }^{25}$ " The person who cares for the sick has an opportunity to touch and nurse the wounds of Christ. For this reason, each encounter with the sick is significant.

Archbishop Zimowski had such an awareness of the significance of spending time with the sick. For this reason, in order to arouse this awareness in others, he said the following during his message in preparation for the 2016 World Day of Rare Diseases: "The sick are those who appeal (interpella) to our sensitivity by the very fact that they are people in need. This is what Jesus taught us in the parable of the Good Samaritan. Love that begins with inner compassion and is expressed through gestures that convey closeness and care is capable of giving life its full relational meaning. Solidarity is enriched by sharing: "to be...with," as well as sacrifice: "to be...for." ${ }^{26}$ When the Archbishop wrote these words, he knew what they meant because he, too, was suffering from a serious illness. As he lay in his hospital bed with pancreatic cancer, the Archbishop experienced the solidarity of those who shared in his suffering ("to be...with") and sacrificed for

$24 \quad$ Francis, "Message $22^{\text {nd }}$ World Day of the Sick," 3.

$25 \quad$ Francis, "Address during the Meeting with the Sick and Disabled Children Assisted at the Seraphic Institute," (Assisi, Italy: October 4, 2013), https:// w2.vatican.va/content/francesco/en/speeches/2013/october/documents/papafrancesco_20131004_bambini-assisi.html.

$26 \quad$ Z. Zimowski, Messaggio del Presidente del Pontificio Consiglio per gli Oparatori Sanitari in occasione della IX Giornata Mondiale delle Malattie Rare [Message of the President of the Pontifical Council for Health Care Workers on the Occasion of the World Day of Rare Diseases]," February 22, 2016, http://www. vatican.va/roman_curia/pontifical_councils/hlthwork/documents/rc_pc_hlthwork_doc_2016022̄9_malattie-rare_it.html, (Accessed: 11.15.2016). 
Moral theology

him ("to be...for"). It was during this time that he developed his idea to organize a symposium in Rome that would draw the health care community's attention to the suffering of the sick and to their exclusion from society, particularly in developing nations. He also wanted to point out the need for a humanization of medicine that "considers all aspects of the person who suffers, including his life and dignity. Secondly, [he expressed that] the inequality of access to primary care that exists among countries and different geographical regions of the world is unacceptable. Even today millions of people die from infections and diseases. Lives could have been spared simply by providing the minimal medical infrastructure and access to medicine that is available elsewhere." ${ }^{27}$

Doctors, nurses, and all personnel involved in health care are servants of life. Consequently, in addition to being professionally competent, they should strive to attain the qualities necessary to fulfill their role as evangelizers of life and to share the message of Evangelium vitae. According to Archbishop Zimowski, "this gospel needs ordinary, modest, sensitive, wounded, trustworthy, enthusiastic people who love the things of God." ${ }^{28}$ This determines the universal aspect of their work in service of life and all its dynamism, dimensions, and sanctity:

Individuals who care for those in need must first be professionally competent: they should be properly trained in what to do and how to do it, and committed to continuing care. Yet, while professional competence is a primary, fundamental requirement, it is not of itself sufficient. We are dealing with human beings, and human beings always need something more than technically proper care. They need humanity. They need heartfelt concern. Those who work for the Church's charitable organizations must be distinguished by the fact that they do not merely meet the needs of the moment, but they dedicate themselves to others with heartfelt concern, enabling them to experience the richness of their humanity. Consequently, in addition to their necessary professional training, these charity workers need a "formation of the heart": they need to be led to that encounter with God in Christ which awakens their love and opens their spirits to others. As a result, love of neighbor will no longer be for them a commandment imposed, so

\footnotetext{
27 Z. Zimowski, Na drodze człowieka cierpiacego Bóg nawiedził lud swój (Lublin: Wydawnictwo KUL, 2013), 239. 
to speak, from without, but a consequence deriving from their faith, a faith which becomes active through love (cf. Gal 5:6). ${ }^{29}$

\section{WKŁAD ARCYBISKUPA ZYGMUNTA ZIMOWSKIEGO W KSZTAŁTOWANIE SŁUŻBY ZDROWIA JAKO STRÓŻA I SŁUGI ŻYCIA}

Zmarły przed rokiem (w chwili przekazywania tego artykułu do druku mija niemal dokładnie pierwsza rocznica śmierci) Arcybiskup Zygmunt Zimowski, Przewodniczący Papieskiej Rady ds. Duszpasterstwa Chorych i Służby Zdrowia, włączonej już w struktury Rady ds. Rozwoju Integralnego Człowieka, z wielkim zaangażowaniem realizował zadanie prowadzenia i wspierania chorych i cierpiących oraz pracowników służby zdrowia w coraz bardziej złożonym świecie. Zależało księdzu arcybiskupowi, aby papieska dykasteria opiekowała się nie tylko pracownikami służby zdrowia, ale obejmowała swą troską chorych. Oni to bowiem mają prawo do takiej opieki lekarskiej, która może być określona jako służba życiu. Niniejszy artykuł ukazuje misję pracowników służby zdrowia, jako służbę życiu w jego różnorakich wymiarach. Jest to służba polegająca na przywracaniu życiu jego harmonii, zintegrowaniu funkcji życiowych organizmu oraz wzajemnej integracji różnych sfer życia człowieka: fizycznej, duchowej, psychicznej, religijnej. Modelem takiej służby jest styl działania samego Boga, który na kartach Pisma Świętego często występuje w roli lekarza. Służba zdrowia to także służba przywracania życiu jego dynamiki, żywotności pozwalającej żyć pełnią możliwości witalnych osoby. Jest to także służba świętości życia, a nawet służba Ewangelii życia, które wyznaczają pracownikom służby zdrowia określony kierunek relacji do osoby chorego i rzeczywistości cierpienia.

Słowa kluczowe: choroba, służba, życie.

\section{Bibliography:}

1. Benedict XVI. Deus Caritas Est, Encyclical Letter. Vatican City, Italy: Libreria Editrice Vaticana, 2005.

2. Chrostowski, W. "Lekarz i jego posługa w świetle Biblii." Collectanea Theologica, Vol. 3 (2001): 51-67.

3. Francis. "Message His Holiness for the $23^{\text {rd }}$ World Day of the Sick 2015," February 2, 2015. Vatican City, Italy: Libreria Editrice Vaticana, 2015, 2. https://w2.vatican.va/content/francesco/en/messages/sick/documents/ papa-francesco_20141203_giornata-malato.html.

29 Benedict XVI, Deus Caritas Est, Encyclical Letter (Vatican City, Italy: Libreria Editrice Vaticana, 2005), 31. 
Moral theology

4. Francis. "Address during the Meeting with the Sick and Disabled Children Assisted at the Seraphic Institute," October 4, 2013. Assisi, Italy. https:// w2.vatican.va/content/francesco/en/speeches/2013/october/documents/ papa-francesco_20131004_bambini-assisi.html.

5. Imiela, J. "Cierpienie - spojrzenie lekarza." Ból i cierpienie - ognisko światta i ciemności. Medycyna - Teologia - Kultura, Vol. 4. Edited by D. Pater. Warsaw: 2016, 9-14.

6. John Paul II. Apostolic Letter: Salvifici Doloris. Vatican City, Italy: Liberia Editrice Vaticana, 1984.

7. John Paul II, "Address at the Conclusion of the $35^{\text {th }}$ General Assembly of the World Medical Association," October 29, 1983 (Vatican City, Italy: Libreria Editrice Vaticana, 1983), https://w2.vatican.va/content/john-paul-ii/ en/speeches/1983/october/documents/hf_jp-ii_spe_19831029_ass-medicamondiale.html.

8. John Paul II. "Address to the Elderly and the Sick, "Your Suffering is Part of Christ's Cross."' World Federation of the Catholic Medical Associations. September 11, 1983. http:/www.fiamc.org/texts/your-suffering-is-part-ofchrists-cross/ (Accessed: 10.17.2017).

9. John Paul II. Katecheza środowa "W ciężkiej chorobie." In Jan Pawet II, Benedykt XVI rozważaja Psalmy. Izabelin-Warsaw: Rosikon Press, 2006, 98-99.

10. Mędala, S. Ewangelia wedtug świętego Jana, Rozdziaty 1-12. No.1. Częstochowa: Edycja Świętego Pawła, 2010.

11. Paglia, V. Sorella morte. La dignità del vivere e del morire. Milan: Pickwick, 2016.

12. Pontifical Council for Healthcare Workers. Nuova Carta degli Operatori Sanitari. Vatican City, Italy: Libreria Editrice Vaticana, 2016.

13. Romaniuk, K., A. Jankowski, and L. Stachowiak. Komentarz praktyczny do Nowego Testamentu. Vol. 1 Poznan-Cracow: Wydawnictwo WAM, 1999.

14. Skarżyński, H. "Niedosłuch i głuchota przyczyną izolacji, bólu i cierpienia." Ból i cierpienie - ognisko światta i ciemności. Medycyna-Teologia - Kultura. Vol 3. Edited by D. Bard. Warsaw: 2015, 9-12.

15. Wojtkun, J. "Posługa hospicyjna alumnów jako element formacji do kapłaństwa." Musicam Sacram dilexit. Księga pamiatkowa dedykowana Księdzu Henrykowi Ćwiekowi profesorowi wyższych seminariów duchownych $w$ Sandomierzu i Radomiu: Studia i materiaty." Edited by M. Jagodziński, S. Kowalik, and A. Wąsik. Radom: Wyższe Seminarium Duchowne; Instytut Technologii Eksploatacji-Państwowy Instytut Badawczy, 2017, 313-322.

16. Zimowski, Z. "Conferrenza Stampa di presentazione della XXI Giornata Mondiale del Malato 11.02.2013 [Press Release on the XXI World Day of the Sick on February 11, 2013]." January 20, 2013. Vatican City, Italy. http:// www.vatican.va/roman_curia/pontifical_councils/hlthwork/documents/ rc_pc_hlthwork_doc_20130129_world-day-of-the-sick_it.html, (Accessed:

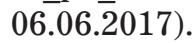

17. Zimowski, Z. "Messaggio del presidente del Pontificio Consiglio per gli Operatori Sanitari per la $57^{\circ}$ Giornata Mondiale dei Malati di Lebbra 
[Message of the President of the Pontifical Council for Health Care Workers on the Occasion of the $57^{\text {th }}$ World Leprosy Day]." January 31, 2010. http://www.vatican.va/roman_curia/pontifical_councils/hlthwork/ documents/rc_pc_hlthwork_doc_20100129_lebbra_it.html (Accessed: 06.06.2017).

18. Zimowski, Z. "Message of the President of the Pontifical Council for theology Health Care Workers on the Occasion of the $59^{\text {th }}$ World Leprosy Day," January 29, 2012. http:/www.vatican.va/roman_curia/pontifical_councils/ hlthwork/documents/rc_pc_hlthwork_doc_20120127_lebbra_en.html (Accessed: 10.27.2017).

19. Zimowski, Z. "Messaggio del Presidente del Pontificio Consiglio per gli Oparatori Sanitari in occasione della IX Giornata Mondiale delle Malattie Rare [Message of the President of the Pontifical Council for Health Pastoral Care on the Occasion of the World Day of Rare Diseases]." February 22, 2016. http://www.vatican.va/roman_curia/pontifical_councils/hlthwork/ documents/rc_pc_hlthwork_doc_20160229_malattie-rare_it.html (Accessed: 11.15 .2016$)$.

20. Zimowski, Z. Na drodze człowieka cierpiacego Bóg nawiedzit lud swój. Lublin: Wydawnictwo KUL, 2013. 